\title{
GREATER SAGE-GROUSE MOVEMENTS AND HABITAT USE DURING WINTER IN CENTRAL OREGON
}

\author{
Jennifer R. Bruce ${ }^{1,4}$, W. Douglas Robinson ${ }^{1}$, Steven L. Petersen ${ }^{2}$, and Richard F. Miller ${ }^{3}$
}

\begin{abstract}
AвSTRACT.-Greater Sage-Grouse (Centrocercus urophasianus) depend on sagebrush habitat for food and cover during winter, yet few sage-grouse winter ecology studies have been conducted. During January and February 2007, we monitored 22 radio-collared sage-grouse ( 7 females and 15 males) in central Oregon to characterize winter habitat use and movement patterns. We estimated distances traveled between locations on a weekly basis and quantified habitat characteristics at locations used by male and female sage-grouse. The birds we collared moved extensively across the landscape, using approximately $1480 \mathrm{~km}^{2}$. Sagebrush canopy height in sites used by sage-grouse varied from 0.25 to $0.75 \mathrm{~m}$, with females tending to be found in sites with taller sagebrush and less foliar cover than in sites where we found males. The difference in foliar cover between sexes was related to a seasonal change in habitat use: 4 females found in little sagebrush (Artemisia arbuscula) in January and early February were no longer located nor found foraging in little sagebrush after 15 February. Also, by this date, most male sage-grouse had stopped using big sagebrush (Artemisia tridentata) as they migrated to leks. Sage-grouse mortality rates were low during our study, which may be attributed to the study area receiving half the long-term average amount of snow. The large area over which sage-grouse moved during winter indicates that conservation of Greater Sage-Grouse may require preservation of sagebrush at landscape scales (thousands of square kilometers).
\end{abstract}

REsumen.-El urogallo de la salvia (Centrocercus urophasianus) depende del hábitat de la salvia para alimento y abrigo durante el invierno, sin embargo se han llevado a cabo pocos estudios sobre su ecología invernal. Monitoreamos 22 urogallos de salvia (7 hembras y 15 machos) con radio collares en el centro de Oregón para caracterizar su uso del hábitat en invierno y los patrones de movimiento durante enero y febrero de 2007. Estimamos las distancias recorridas entre sitios cada semana, y cuantificamos las características del hábitat en los sitios utilizados por urogallos machos y hembras. Las aves con collares se desplazaron ampliamente por toda la región, utilizando aproximadamente $1480 \mathrm{~km}^{2}$. La altura del dosel de las salvias en los sitios utilizados por urogallos varió entre 0.25 y $0.75 \mathrm{~m}$, con hembras encontradas en sitios con salvias más altas y menor cobertura foliar que los sitos en donde encontramos a los machos. La diferencia en cobertura foliar entre los sexos estuvo relacionada con un cambio estacional en el uso del hábitat; las 4 hembras encontradas en la salvia pequeña (Artemisia arbuscula) en enero y a principios de febrero ya no se localizaron o se vio que forrajearan en la salvia pequeña después del 15 de febrero. Además, para esta fecha la mayoría de los urogallos machos habían dejado de utilizar la salvia grande (Artemisia tridentata) a medida que migraron a los leks. Las tasas de mortalidad del urogallo fueron bajas durante nuestro estudio, lo cual se podría atribuir a que el área de estudio recibió la mitad de la cantidad de nieve promedio a largo plazo. La gran área en que se desplazaron los urogallos durante el invierno indica que la conservación del urogallo de la salvia podría requerir la preservación de la salvia a escala regional (miles de kilómetros).

Concomitant with habitat loss, populations of Greater Sage-Grouse (Centrocercus urophasianus) across western North America have dramatically declined. Sage-grouse abundance was reduced by $70 \%$ from 1965 to 1985 and still continues to decline at a rate of $2 \%$ per year (Connelly et al. 2004). These trends have been severe enough for the U.S. Fish and Wildlife Service to designate Greater Sage-Grouse as "warranted but precluded" from listing for protection under the federal Endangered Species Act (ESA). Most sage-grouse studies have focused on habitat use and reproduction during the breeding season (Gregg et al. 1994,
Sveum et al. 1998, Schroeder et al. 1999), but there is a need for a better understanding of factors that influence sage-grouse movements and survival during winter. Although SageGrouse have high overwinter survival in certain locations (Wik 2002, Sika 2006, Knick and Connelly 2010), severe winter weather has been known to contribute to low overwinter survival in southeastern Oregon (Anthony and Willis 2009) and even in high-quality habitat in north central Montana (Moynahan 2006). We studied Greater Sage-Grouse to improve understanding of their winter ecology in central Oregon by (1) measuring the distances

\footnotetext{
${ }^{1}$ Oregon State University, Oak Creek Lab of Biology, Department of Fisheries and Wildlife, 104 Nash Hall, Corvallis, OR 97331-3803. ${ }^{2}$ Brigham Young University, Department of Plant and Wildlife Sciences, 275 WIDB, Provo, UT 84602.

${ }^{3}$ Oregon State University, Eastern Oregon Agricultural Research Station, 302 Strand Hall, Corvallis, OR 97333.

${ }^{3}$ Oregon State University, Eastern Oregon Agricultural Research Station, 302 Strand Hall, Corval
Present address: 406 Lincoln Street, Klamath Falls, OR 97601. E-mail: jennyrbruce@gmail.com
} 
that male and female Greater Sage-Grouse move during winter to describe distribution patterns across the landscape, (2) characterizing habitats occupied (for foraging and for cover) by sage-grouse during winter and determining if sexes are found in different habitats, and (3) quantifying mortality rates of sage-grouse during winter. Evaluating habitat selection requires data from a landscape-level distribution of habitats, which were unavailable to us but are part of another study (Freese 2009). We therefore characterize the habitats sage-grouse used during our study and make no inferences about selection.

We studied Greater Sage-Grouse on public, state, and private land along the western edge of the current geographic range of the Greater Sage-Grouse (Schroeder et al. 2004). These areas were at elevations ranging from $1250 \mathrm{~m}$ to $1950 \mathrm{~m}$. During the study period, mean daily temperatures ranged from $-7.5{ }^{\circ} \mathrm{C}$ to $3.9^{\circ} \mathrm{C}$, and mean precipitation was $1.5 \mathrm{~cm}$ (Oregon Climate Service 2008; Squaw Butte Experimental Station, OR), which is $48 \%$ less precipitation than the long-term average. Vegetation across our study area is semiarid sagebrush rangeland, with dominant overstory cover types of early sagebrush (Artemisia longiloba), little sagebrush (Artemisia arbuscula), mountain big sagebrush (Artemisia tridentata ssp. vaseyana), Wyoming big sagebrush (Artemisia tridentata ssp. wyomingensis), and basin big sagebrush (Artemisia tridentata ssp. tridentata). Lessdominant shrub cover includes green rabbitbrush (Chrysothamnus viscidiflorus) and rubber rabbitbrush (Ericameria nauseosa). Early sagebrush and little sagebrush often grow in adjacent or intermixed patches, and were combined into a little sagebrush growth-form group.

Using a spotlighting technique (Giesen et al. 1982), we opportunistically captured and attached radio-transmitters to 7 female and 15 male sagegrouse from 23 March to 13 December 2006. We tracked movements and monitored locations of each bird every every 10 days $(\mathrm{SD}=3)$ from 8 January to 9 March 2007 . Plots were established to quantify habitat characteristics and browsing evidence within 2 days of each time of location for all sage-grouse with transmitters. To reduce chances of erroneous location information that could be influenced by human approach, presumed activity at the time of sighting was determined by sign (fresh feces, cecal droppings, or tracks in snow and mud) and evidence of foraging. A systematic search for sage-grouse foraging evidence was possible because identification of plants browsed by sage-grouse can be reliably determined (Remington and Braun 1985).

We calculated the minimum distance traveled between each location using the Distances Between Points analysis function in Hawth's Tools (Beyer 2004), an extension of ArcGIS 9.2 (ESRI 1999-2006). We estimated mean daily movement for each sage-grouse by dividing the minimum distance traveled by the number of days between each location date. Calculating the linear distance between locations over a period of a week likely underestimates average distances moved on a daily basis. Therefore, we refer throughout this manuscript to distances traveled as an abbreviated way of saying estimated minimum distances traveled. We measured topography using a compass, GPS unit, and a slope-based grid layer derived from the Spatial Analyst Tool in ArcView 9.2 (ESRI 1999-2006). To quantify live and dead foliar cover, we used a line-point intercept method that differs slightly from that used by previous researchers (Herrick et al. 2005), and later grouped shrub foliar cover by species. We used a meterstick at the center of each plot to estimate mean sagebrush height $( \pm 2 \mathrm{~cm})$. Snow depth was systematically measured but was not included in the description of winter habitat or in the analysis because only a small amount of precipitation fell during the study period. We used a random sample of 25 points within each plot to inspect sagebrush for signs of browsing by sage-grouse. To characterize habitats used, we summarized the average elevation, slope, aspect, percent foliar cover, and shrub height for all plot locations; quantified and compared species of shrubs (and subspecies of Artemisia) for each plot; and determined the frequency of plots with foraging evidence and relative frequency of browsing within each plot. See Bruce (2008) for additional details.

We used a nonparametric Mann-Whitney $U$ test to determine if there was a significant difference among males and females in minimum distance moved and average daily movements. Movement comparisons were made for 20 of the 22 total birds, as 2 sage-grouse were only found once. Unless otherwise noted, we considered $P$ values $\leq 0.05$ statistically significant. Using all 22 collared birds and a MannWhitney $U$ test, we compared the characteristics of habitats used during winter by males against 


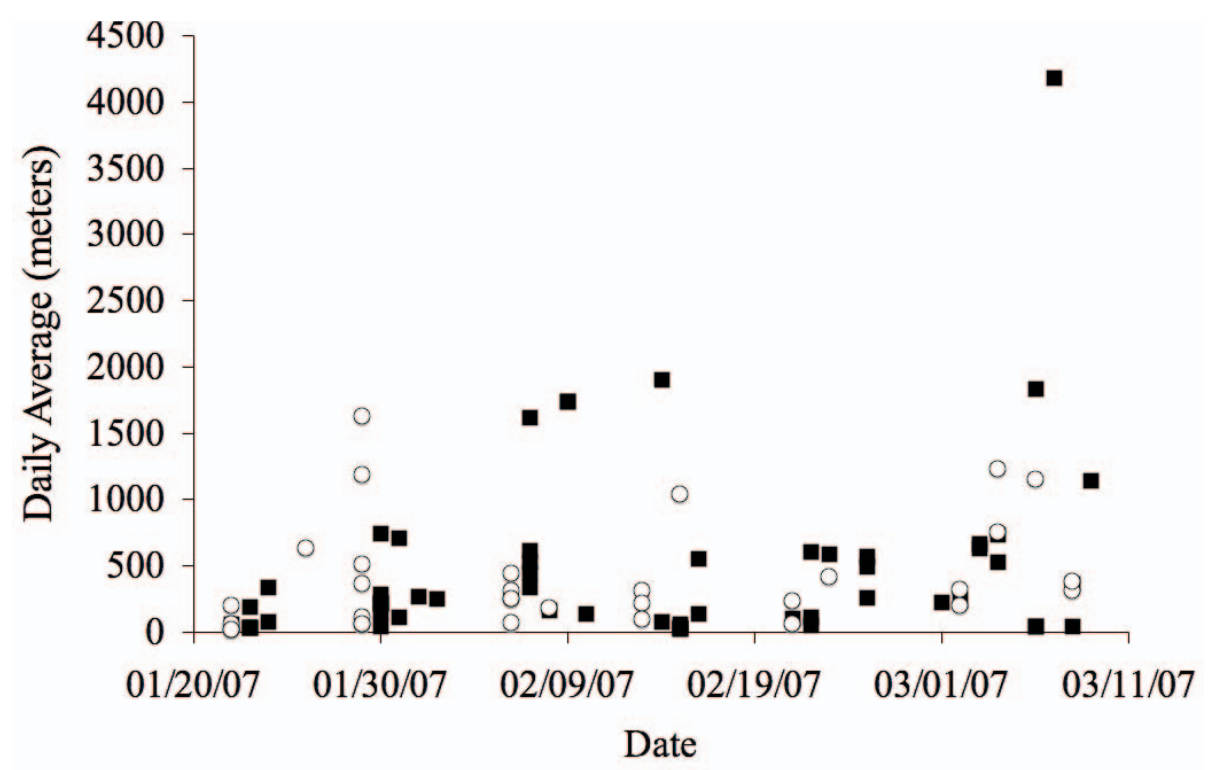

Fig. 1. Average daily distances moved between locations by female (open circles) and male (solid squares) Greater Sage-Grouse in central Oregon. Dates are 20 and 30 January, 9 and 19 February, and 1 and 11 March 2007.

TABLE 1. Male and female Greater Sage-Grouse in central Oregon were found at similar time intervals and moved similar distances from 8 January to 9 March 2007. Minimum distances are defined as the straight-line distances calculated between 2 locations.

\begin{tabular}{|c|c|c|c|c|c|c|}
\hline \multirow[b]{2}{*}{ Movement variable } & \multicolumn{3}{|c|}{ Female } & \multicolumn{3}{|c|}{ Male } \\
\hline & $n$ & Mean (SD) & Range & $n$ & Mean $(\mathrm{SD})$ & Range \\
\hline Minimum distance $(\mathrm{m})$ & 7 & 4005 (2948) & $833-8849$ & 13 & $4031(3227)$ & $891-12807$ \\
\hline Days between locations & 7 & $9(2)$ & $7-11$ & 13 & $10(3)$ & 6-14 \\
\hline Daily average distance (m) & 7 & $427(276)$ & $107-845$ & 13 & $426(284)$ & $85-1045$ \\
\hline
\end{tabular}

habitats used by females. When more than one plot had been measured per bird, we used the mean values from all plots measured per bird in our comparisons among birds. We used indicator variables for aspect, with flat ground equaling $0^{\circ}$ and degree ranges assigned to the 8 cardinal and subcardinal directions. We report mortality, which was a simple percentage of death during the study period, as well as daily mortality rate, which was calculated by dividing the number of mortality events observed by the total number of days radio-tagged sage-grouse were known to be alive during the study and then converted to a percentage. We used this simple approach because only one sage-grouse died during our study.

We located 7 females and 13 males 2-7 times from 8 January to 9 March 2007 (Table 1). The mean distance traveled during the study was similar $(4 \mathrm{~km})$ for both females and males $(U$ test:
$P>0.95)$. Mean daily movements were also nearly identical ( $U$ test: $P>0.95$; Table 1$)$. Distances moved throughout most of the study period were relatively consistent among sagegrouse; however, we observed 2 exceptions related to migration toward leks. First, 4 males began moving to leks in mid-February, and their average daily movements increased from $1.5 \mathrm{~km}$ to $2 \mathrm{~km}$ during that period (Fig. 1). Second, 4 females and the remaining males moved longer distances toward leks as spring breeding season approached. Four of the 6 surviving females moved approximately $10 \mathrm{~km}$ toward leks at the end of February, while the other 2 moved $37 \mathrm{~km}$ to leks in April 2007. The longest daily average distance moved toward a lek was by a male who moved $4.2 \mathrm{~km}$ per day for 3 days at the beginning of March. The longest distance moved by a male sage-grouse was $38 \mathrm{~km}$ from one lek to another in early March. 
By the end of the study period, all males had migrated to leks, whereas only $66 \%$ of females were detected at leks. Overall, male and female sage-grouse moved an average of $425 \mathrm{~m}$ per day during late winter; males tended to move farther to leks in early spring than did females.

The area delineated by locations from all 22 grouse during the winter study period was approximately $1480 \mathrm{~km}^{2}$. We measured 81 plots used by 22 sage-grouse. Thirty-three plots were from 7 females, and 48 were from 15 males. Of all plots measured, $94 \%$ had evidence of plot use in addition to observation of the birds at each location. Of plots with evidence of use, 75\% had been foraged and $25 \%$ contained other signs including tracks, fecal droppings, and/or cecal droppings. The frequency of plants browsed per plot by females was $14 \%$ (SD $=10 \%$, range $0 \%-65 \%$, whereas frequency browsed by males was $20 \%$ ( $\mathrm{SD}=11 \%$, range $0 \%-61 \%$ ). The only habitat variable that differed significantly in plots used by males versus plots used by females was percent live total shrub cover (Fig. 2). Females used sites with less live total shrub cover on average than males did, but values in plots used by males were variable, causing ranges to overlap. Females also tended to use sites with taller cover. Average canopy height was $0.54 \mathrm{~m}$ (SD = 0.17 , range $0.28-0.75$ ) in plots used by females compared to $0.37 \mathrm{~m}(\mathrm{SD}=0.10$, range $0.25-0.63)$ in plots used by males.

Seventy-five percent of female locations and $60 \%$ of male locations were found on sites with $<2 \%$ slope. Of locations with $>2 \%$ slope, the mean slopes used by both sexes were similar $(4 \%-5 \%, \mathrm{SD}=4 \%)$. When sage-grouse were not on flat ground, the greatest percentage of them were found on a northeast-facing aspect (38\% of females and $32 \%$ of males were found on aspects facing northeast compared to smaller percentages for the other 7 cardinal and subcardinal directions).

We found little sagebrush, and both mountain and Wyoming big sagebrush to be the most frequent cover types encountered in winter habitat plots, while both gray and green rabbitbrush species were the only common nonsagebrush shrub encountered. Four plots were located in silver sagebrush (Artemisia cana), but only females were associated with this sagebrush species. Other plant species encountered include basin big sagebrush, stiff sagebrush (Artemisia rigida), antelope bitterbrush (Purshia tridentata), rock buckwheat (Eriogonum sphaercephalum), and western juniper (Juniperus occidentalis). Males and females used plots with different dominant shrubs providing cover (Table 2). Females used plots with a greater percentage of big sagebrush and silver sagebrush cover, whereas males used plots with a greater percentage of little sagebrush and rabbitbrush cover. Of all sage-grouse plots in big sagebrush, $80 \%$ were in Wyoming big sagebrush whereas $20 \%$ were mountain big sagebrush. Percent survival of the 22 birds captured and collared was $96 \%$. Only one female sage-grouse perished; the estimated date of death was $24 \mathrm{Feb}-$ ruary 2007. The mean number of exposure days during the winter study period for sagegrouse that were located more than once was 373 for females and 780 for males, with corresponding daily mortality rates of $2 \%$ and $0 \%$.

We found that sage-grouse were most often observed using little sagebrush as forage, which may be due to the increased palatability of little sagebrush over big sagebrush subspecies (Rosentreter 2005). However, even though snow depth was presumed to be a factor driving sage-grouse into taller sagebrush in a study by Barrington and Back (1984), Wyoming and mountain big sagebrush were still used during our study even with little snow cover and high availability of little sagebrush. We measured the range of the total average canopy height, without snow, as $0.25-0.75 \mathrm{~m}$, which falls within ranges measured in Colorado and Idaho $0.41-0.56 \mathrm{~m}$; Connelly et al. 2000) and in Utah $(0.40-0.60 \mathrm{~m}$; Homer et al. 1993). We found sage-grouse on northeast-facing slopes, which contrasts with other studies that typically found flocks located on south- to west-facing slopes (Beck 1977, Crawford et al. 2004). However, we found $75 \%$ of female locations and $60 \%$ of male locations on sites with $<2 \%$ slope, which is a result similar to Beck (1977) in that $60 \%-70 \%$ of sagegrouse were located in areas with $<5 \%$ slope.

We found that the mean movements of sagegrouse to and from wintering areas in central Oregon $(15.8 \mathrm{~km})$ were within the range of distances measured in past studies in Colorado and southeastern Idaho $(5.3 \mathrm{~km}-19.2 \mathrm{~km}$; Beck 1977, Connelly et al. 1988). The average daily movements during winter were $0.42 \mathrm{~km}$ in our study, which falls within the average daily movements measured in southeastern Idaho (0.3$0.8 \mathrm{~km}$; Connelly et al. 1988, Robertson 1991) but is $35 \%$ less than the reported minimum 
A

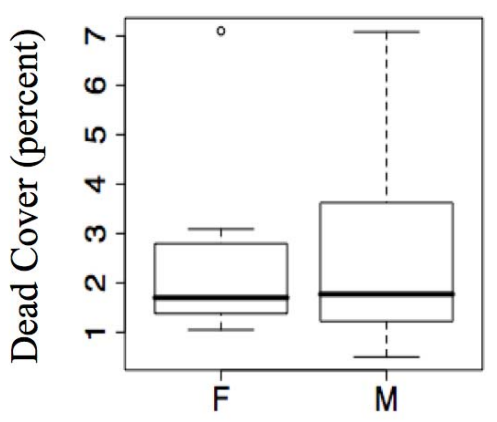

Sex

C

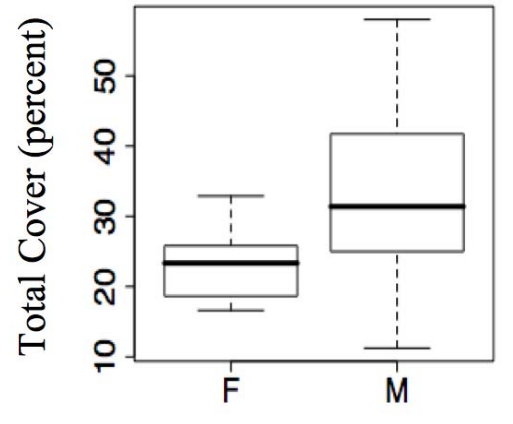

Sex

E

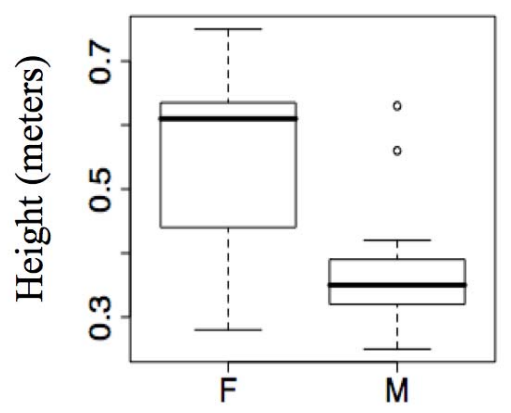

Sex
B

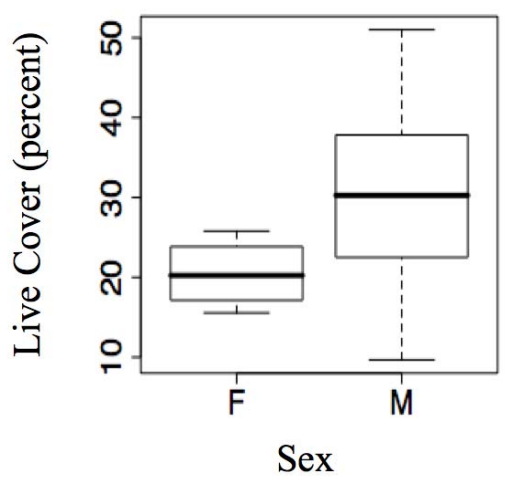

D

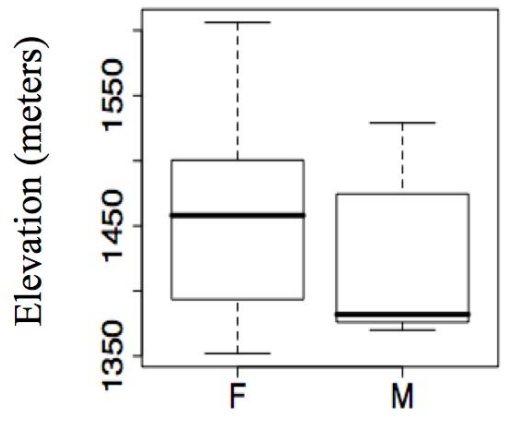

Sex

F

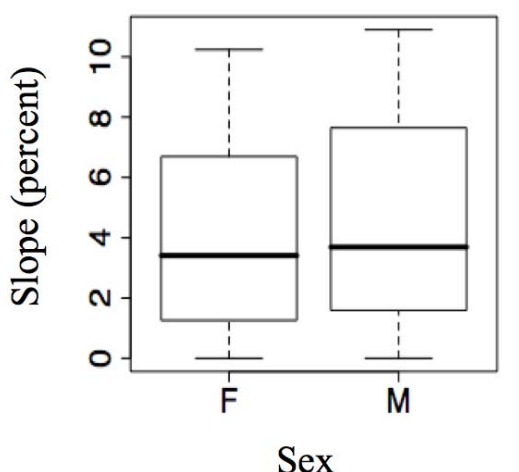

Fig. 2. Winter habitat characteristics of plots used by male and female Greater Sage-Grouse in central Oregon. Figures illustrate means (heavy lines), standard deviations (box outlines), and ranges (whisker bars); outliers are depicted by circles. $\mathrm{U}$ test statistics and $\mathrm{P}$ values for each panel are as follows: $\mathbf{A}, U=82.0, P=0.94 ; \mathbf{B}, U=50, P=0.03 ; \mathbf{C}, U=55, P=0.08$; $\mathbf{D}, U=87, P=0.67 ; \mathbf{E}, U=107, P=0.07 ; \mathbf{F}, U=74.5, P=0.70$.

daily movements of up to $1.21 \mathrm{~km}$ in central Montana (Eng and Schladweiler 1972). However, Eng and Schladweiler (1972) based their calculations on daily locations of each bird, while we located each bird every 7-13 days, which underestimates average daily distances moved. Therefore, our estimates of distances moved should be considered conservative. The $1480-\mathrm{km}^{2}$ area utilized in winter by this small sample of a larger sage-grouse population 
TABLE 2. Percent composition of shrub species cover present in habitat plots differed among male and female Greater Sage-Grouse in central Oregon during winter, 2006-2007.

\begin{tabular}{|c|c|c|c|c|c|c|}
\hline \multirow[b]{2}{*}{ Plant species } & \multicolumn{3}{|c|}{ Female } & \multicolumn{3}{|c|}{ Male } \\
\hline & $n$ & Mean (SD) & Range & $n$ & Mean (SD) & Range \\
\hline A. arbuscula & 7 & $11.2(11.5)$ & $0-28.2$ & 15 & $23.6(9.3)$ & $2.8-37.0$ \\
\hline A. tridentata ${ }^{\mathrm{a}}$ & 7 & $6.7(3.7)$ & $0-11.7$ & 15 & $2.3(3.3)$ & $0-12.3$ \\
\hline A. cana $^{\mathrm{a}}$ & 7 & $3.3(5.8)$ & $0-15.2$ & 15 & $0.0(0.0)$ & 0 \\
\hline C. viscidiflorus ${ }^{\mathrm{a}}$ & 7 & $1.1(0.9)$ & $0-2.7$ & 15 & $5.9(4.6)$ & $0.5-17.7$ \\
\hline Othera & 7 & $0.9(2.0)$ & $0-5.3$ & 15 & $1.8(1.4)$ & $0.1-5.0$ \\
\hline
\end{tabular}

aSignificant difference between sexes, Mann-Whitney $U$ test, $P<0.05$.

supports the need to manage habitats across large spatial extents in central Oregon.

The high survival rate of $96 \%$ in our study area falls within the range reported in southwestern Idaho (85\%-100\%; Wik 2002) and is similar to the survival of adult females in Montana (97\%-98\%; Sika 2006), but this survival rate is greater than the survival rate of adult females reported in Alberta, Canada (73\%-88\%; Aldridge et al. 2004). Differences in food accessibility due to snow cover may be a main factor in the contrast between studies.

January through March includes a transition period between late winter and spring for Greater Sage-Grouse. From mid-February through March, males and females begin preparing for the breeding season. In the year of our study, groups of males were first seen strutting at leks on 10 February, although many males did not arrive at leks until approximately 2 weeks later. The average first copulation date for sage-grouse in Oregon is in late March (Batterson and Morse 1948), and 1-2 weeks before copulation, females begin to seek out nesting habitats that provide a specific type of cover for nesting (Bradbury et al. 1989). Therefore, our study encompasses the transition between winter and very early spring.

Funding was provided by a graduate research assistantship from Oregon State University and George Buckner of the Prineville Bureau of Land Management. We thank the GI Ranch for allowing us to conduct surveys on their private land, our technician Neil Holocomb for all his hard work and patience, and pilots Andrew Menlow from Oregon State Police and Jack Hodnett from Wildlife Services. Northwest Habitat Institute facilitated our work. We also thank Heather Carlisle, Jan Hanf, Marcie Lima-Baumbach, Mark Freese, James Rebholz, Aaron Holmes, and all the volunteers who helped capture sage-grouse for their kind assistance in this effort.

\section{Literature Cited}

Aldridge, C.L., R. Lee, P. Jones, And J. Nicholson. 2004. Winter habitat selection and survival by sagegrouse in southeastern Alberta. Final unpublished report, prepared for 2002-2004 Winter Sage-Grouse Funding Partners. Department of Biological Sciences, University of Alberta, Edmonton, Alberta, Canada. 22 pp.

Anthony, R.G., AND M.J. Willis. 2009. Survival rates of female Greater Sage-Grouse in autumn and winter in southeastern Oregon. Journal of Wildlife Management 73:538-545.

Barrington, M.R., AND G.N. BaCK. 1984. Sage grouse research: population dynamics. Pages 43-146 in P.C. Lent and R.E. Eckert, Jr., editors, Progress report 1983, Saval Ranch Research and Evaluation Project. University of Nevada-Reno, Renewable Resource Center, Reno, NV

Batterson, W.M., And W.B. Morse. 1948. Oregon sage grouse. Oregon State Game Commission, Portland, OR. Fauna Ser. No. 1. 29 pp.

BECK, T.D.I. 1977. Sage grouse flock characteristics and habitat selection in winter. Journal of Wildlife Management 41:18-26.

BEYER, H.L. 2004. Hawth's analysis tools for ArcGIS. Available from: http://www.spatialecology.com/htools

Bradbury, J.W., R.M. Gibson, C.E. McCarthy, and S.L. VEHRENCAMP. 1989. Dispersion of displaying male sage grouse. II. The role of female dispersion. Behavioral Ecology and Sociobiology 24:15-24.

Bruce, J.R. 2008. Greater Sage-Grouse movements and habitat use during winter in central Oregon. Master's thesis, Oregon State University, Corvallis, OR.

Connelly, J.W., H.W. Browers, and R.J. Gates. 1988. Seasonal movements of sage grouse in southeastern Idaho. Journal of Wildlife Management 52:116-122.

Connelly, J.W., S.T. KNICK, M.A. Schroeder, AND S.J. STIVER. 2004. Conservation assessment of Greater Sage-Grouse and sagebrush habitats. Unpublished report, Western Association of Fish and Wildlife Agencies, Cheyenne, WY.

Connelly, J.W., M.A. Schroeder, A.R. Sands, and C.E. Braun. 2000. Guidelines for management of sage grouse populations and their habitats. Wildlife Society Bulletin 28:967-985.

Crawford, J.A., R.A. Olsen, N.E. West, J.C. Mosley, M.A. Schroeder, TD. Whitson, R.F Miller, M.A. 
GREgG, AND C.S. Boyd. 2004. Ecology and management of sage-grouse and sage-grouse habitat. Journal of Range Management 57:2-19.

ENG, R.L., AND P. SCHLADWEILER. 1972. Sage grouse winter movements and habitat use in central Montana. Journal of Wildlife Management 36:141-146.

[ESRI] ENVIRONMENTAL Systems RESEARCH Institute, InC. 1999-2006. ArcGIS 9.2. ESRI, Redlands, CA

Freese, M.T. 2009. Linking Greater Sage-Grouse habitat use and suitability across spatiotemporal scales in central Oregon. Master's thesis, Oregon State University, Corvallis, OR.

Giesen, K.M., T.J. Schoenberg, and C.E. Braun. 1982. Methods for trapping sage grouse in Colorado. Wildlife Society Bulletin 10:224-231.

Gregg, M.A., J.A. Crawford, M.S. Drut, and A.K DELONG. 1994. Vegetational cover and predation of sage grouse nests in Oregon. Journal of Wildlife Management 58:162-166.

Herrick, J.E., J.W. Van ZeE, K.M. Havstad, L.M. Burkett, AND W.G. WhitForD. 2005. Monitoring manual for grassland, shrubland and savanna ecosystems. Volume I, Quick start. United States Department of Agriculture, ARS Jornada Experimental Range, Las Cruces, NM.

Homer, C.G., T.C. Edwards JR., R.D. Ramsey, and K.P PRICE. 1993. Use of remote sensing methods in modeling sage grouse winter habitat. Journal of Wildlife Management 57:78-84

KNICK, S.T., AND J.W. ConNelly, EDITORS. 2010. Ecology and conservation of Greater Sage-Grouse: a landscape species and its habitats. In: Studies in avian biology. University of California Press, Berkeley, CA. Available from: http://sagemap.wr.usgs.gov/monograph .aspx

Moynahan, B.J., M.S. LindberG, And J.W. Thomas. 2006. Factors contributing to process variance in annual survival of female Greater Sage-Grouse in north-central Montana. Ecological Applications 16:1529-1538.
Oregon Climate Service. 2008. Zone 7 Climate Data Archives (Squaw Butte Experimental Station, Oregon) [online]. [Cited 20 February 2009]. Available from: http://www.ocs.oregonstate.edu/index.html

Remington, T.E., and C.E. Braun. 1985. Sage grouse food selection in winter, North Park, Colorado. Journal of Wildlife Management 49:1055-1061.

RoberTson, M.D. 1991. Winter ecology of migratory sage grouse and associated effects of prescribed fire in southeastern Idaho. Master's thesis, University of Idaho, Moscow, ID.

Rosentreter, R. 2005. Sagebrush identification, ecology, and palatability relative to sage-grouse. RMRS-P-38, USDA Forest Service.

Schroeder, M.A., C.L. Aldridge, A.D. ApA, J.R. Bohne, C.E. Braun, S.D. Bunnell, J.W. Connelly, P.A. Deibert, S.C. Gardner, M.A. Hilliard, et al. 2004 Distribution of sage-grouse in North America. Condor 106:363-376.

Schroeder, M.A., J.R. Young, and C.E. Braun. 1999. Sage Grouse (Centrocercus urophasianus). No. 425 in A. Poole and F. Gill, editors, The birds of North America. Birds of North America, Inc., Philadelphia, PA.

SIKA, J.L. 2006. Breeding ecology, survival rates, and causes of mortality of hunted and nonhunted Greater SageGrouse in central Montana. Master's thesis, Montana State University, Bozeman, MT.

Sveum, C.M., J.A. Crawford, And W.D. Edge. 1998. Use and selection of broodrearing habitat by sage-grouse in south-central Washington. Great Basin Naturalist 58:344-351.

WIK, P.A. 2002. Ecology of Greater Sage-Grouse in southcentral Owyhee County, Idaho. Master's thesis, University of Idaho, Moscow, ID.

Received 8 August 2010 Accepted 5 April 2011 